\title{
DESKRIPSI BERPIKIR ALJABAR SISWA KELAS XI DALAM MENYELESAIKAN SOAL PROGRAM LINEAR
}

\section{(ALGEBRAIC THINKING DESCRIPTION OF STUDENT GRADE XI IN SOLVING LINEAR PROGRAMMING PROBLEMS)}

\author{
Donny Dwi Farisdianto ${ }^{1}$ \\ 1Universitas Islam Lamongan, donny.dwifa09@gmail.com
}

\begin{abstract}
Abstrak. Berpikir aljabar merupakan salah satu jenis berpikir yang sangat penting dalam mempelajari matematika. Penelitian ini bertujuan untuk mengetahui berpikir aljabar siswa kelas XI dalam menyelesaikan soal program linear. Subjek dalam penelitian ini adalah tiga siswa yang telah diberikan tes kemampuan matematika dan mewakili masing-masing kelompok kemampuan matematika yaitu kemampuan matematika rendah, sedang, dan tinggi. Setelah subjek penelitian ditentukan, maka tiga siswa diberikan soal program linear dan dilakukan wawancara. Hal tersebut dilakukan sebanyak dua kali dalam waktu yang berbeda. Dari hasil tersebut ditemukan sedikit perbedaan, yaitu siswa berkemampuan matematika rendah dalam mencari solusi dari permasalahan tidak menggunakan konsep pada materi program linear dengan benar. Sehingga, hasil tersebut menyarankan kepada pendidik untuk lebih memperhatikan siswa berkemampuan rendah dalam menyelesaikan masalah matematika
\end{abstract}

Kata kunci: Berpikir Aljabar, Penyelesaian Masalah, Program Linear

\begin{abstract}
Algebraic thinking is one of thinking which is very important in learning mathematics. The objective of this research is to know algebraic thinking of student grade XI in solving linear programming problems. The subjects of this research are three students who were given mathematical test and represents each group of mathematics abilities that is low, average, and high mathematical ability. After determined the research subjects, these three students were given linear programming problems and interviewed. This was done twice in the different time. From the result, it was found a bit difference that was the student with low mathematics ability in finding the solution from the problem didn't use the concept on linear programming chapter rightly. Therefore, this result suggests teacher to give more attention to this low mathematical ability student in solving mathematics problems.
\end{abstract}

Keywords: Algebraic thinking, Problem solving, Linear programming 


\section{PENDAHULUAN}

Di era globalisasi saat ini, hampir semua pekerjaan membutuhkan matematika. Banyak cara yang dapat dilakukan untuk mempelajari matematika, salah satunya melalui Pendidikan formal dibangku sekolah. Salah satu materi penting yang diajarkan dalam matematika disekolah adalah aljabar. Aljabar merupakan bahasa simbol dan relasi (Krismanto, 2004). Karena di dalam aljabar mempelajari suatu kuantitas digeneralisasikan ke dalam bentuk simbol dalam menyederhanakan dan menyelesaikan masalah. Berpikir aljabar dapat didefinisikan sebagai penggunaan berbagai macam representasi untuk menangani situasi kuantitatif dengan cara keterhubungan (Kieran, 2005). Salah satu materi sekolah yang berhubungan dengan aljabar adalah program linear. Terdapat dua komponen dalam berpikir aljabar, yaitu alat berpikir matematika dan ide dasar aljabar (Kriegler, 2008). Dalam penelitian ini, peneliti mengadaptasi komponen berpikir aljabar menurut Kriegler. Berikut disajikan tabel komponen berpikir aljabar.

Tabel 1. Indikator Berpikir Aljabar pada Komponen Alat Berpikir Matematika

\begin{tabular}{|c|c|c|}
\hline No & $\begin{array}{c}\text { Subkomponen Alat Berpikir } \\
\text { Matematika }\end{array}$ & Indikator \\
\hline 1 & $\begin{array}{l}\text { Kemampuan Pemecahan } \\
\text { Masalah }\end{array}$ & $\begin{array}{l}\text { Menggunakan strategi pemecahan } \\
\text { masalah }\end{array}$ \\
\hline 2 & Kemampuan Representasi & $\begin{array}{l}\text { Menafsirkan informasi dalam } \\
\text { representasi }\end{array}$ \\
\hline 3 & $\begin{array}{l}\text { Kemampuan Penalaran } \\
\text { Kuantitatif }\end{array}$ & $\begin{array}{l}\text { Mengidentifikasi } \text { unsur-unsur } \\
\text { penting suatu masalah untuk } \\
\text { merencanakan } \\
\text { masalah }\end{array}$ \\
\hline
\end{tabular}

Tabel 2. Indikator Berpikir Aljabar pada Komponen Ide Dasar Aljabar

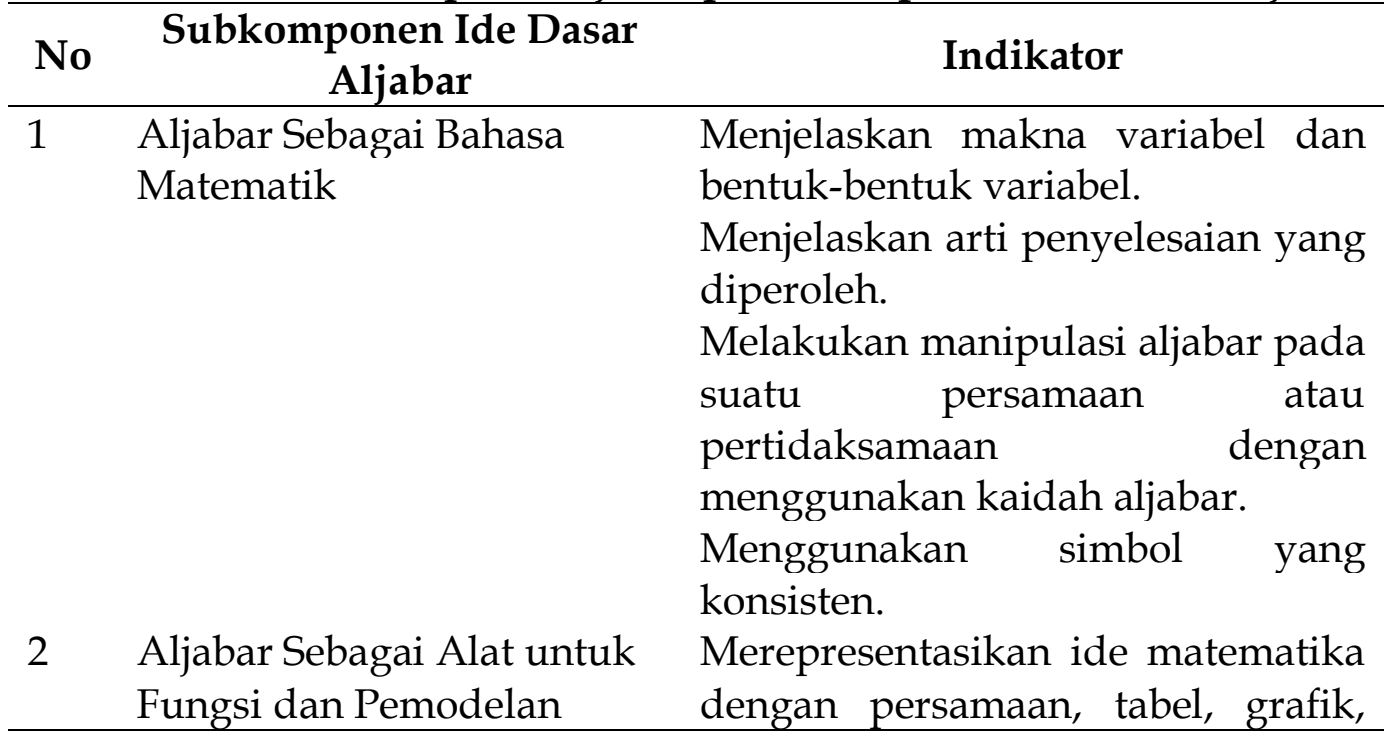

2| Jurnal Pendidikan Matematika dan Matematika Vol. I No. 01 Februari 2019 


\begin{tabular}{lll}
\hline \multirow{2}{*}{ No } & $\begin{array}{c}\text { Subkomponen Ide Dasar } \\
\text { Aljabar }\end{array}$ & \multicolumn{1}{c}{ Indikator } \\
\hline & Matematika & $\begin{array}{l}\text { atau kata-kata. } \\
\text { Bekerja dengan pola input/output. }\end{array}$ \\
&
\end{tabular}

Berbicara tentang berpikir aljabar, maka tak lepas dari kemampuan siswa dalam memecahkan masalah matematika. Pendekatan pemecahan masalah adalah baik untuk digunakan dalam rangka membangun dan mengembangkan pemikiran aljabar (Windsor, 2010). Kemampuan siswa dalam memecahkan masalah matematika berbeda-beda, hal ini dikarenakan dengan tingkat kemampuan matematika siswa berbeda.

\section{METODE}

Tujuan penelitian ini adalah untuk mendeskripsikan kemampuan siswa dalam menyelesaikan soal berpikir aljabar. Berdasarkan tujuan tersebut, maka jenis penelitian ini merupakan penelitian deskriptif dengan menggunakan pendekatan kualitatif.

Pemilihan subjek penelitian adalah kelas XI MIA 2 SMA ULUL ALB@B yang memiliki siswa berjumlah 21 orang. Kelas tersebut dipilih karena berdasarkan informasi dari guru matematika, siswa kelas tersebut memiliki kemampuan matematika yang beragam dan rata-rata siswa pada kelas tersebut memiliki kemampuan komunikasi yang baik. Sehingga, membantu dan memudahkan peneliti untuk mendapatkan subjek yang dapat memberi informasi sesuai kebutuhan peneliti. Selanjutnya, dari 21 siswa diberikan tes kemampuan matematika dan hasilnya dikelompokkan berdasarkan kelompok kemampuan matematika. Kelompok kemampuan matematika dalam penelitian ini terdiri dari kemampuan matematika rendah, kemampuan matematika sedang, dan kemampuan matematika tinggi. Pengelompokan kemampuan matematika siswa berdasarkan dari hasil tes kemampuan matematika yang disesuaikan dengan tingkatan kemampuan matematika yang diadaptasi dari nilai acuan patokan yang dikemukakan oleh Ratumanan (2011) yang dijelaskan pada tabel berikut.

\section{Tabel 3. Kelompok Kemampuan Matematika}

\begin{tabular}{llc}
\hline No & \multicolumn{2}{c}{ Kemampuan Matematika } \\
Siswa & Skor Tes \\
\hline 1 & Rendah & $0 \leq$ Skor Tes $<60$ \\
2 & Sedang & $60 \leq$ Skor Tes $<75$ \\
3 & Tinggi & $75 \leq$ Skor Tes $\leq 100$ \\
\hline
\end{tabular}

Instrumen yang digunakan dalam penelitian ini adalah tes kemampuan matematika, tes berpikir aljabar berupa soal program linear dan pedoman wawancara. Intrumen tes kemampuan matematika 
digunakan untuk mengelompokkan kemampuan matematika siswa yang mewakili masing-masing kelompok. Dari hasil tes kemampuan matematika siswa didapatkan kelompok kemampuan sebagai berikut.

Tabel 4. Pengelompokan Kemampuan Matematika Siswa Kelas XI MIA 2

\begin{tabular}{|c|c|c|}
\hline No & $\begin{array}{c}\text { Kemampuan Matematika } \\
\text { Siswa }\end{array}$ & Jumlah Siswa \\
\hline 1 & Rendah & 14 orang \\
\hline 2 & Sedang & 4 orang \\
\hline \multirow[t]{2}{*}{3} & Tinggi & 3 orang \\
\hline & Total & 21 orang \\
\hline
\end{tabular}

Setelah diperoleh kelompok siswa yang memiliki kemampuan rendah, kemampuan sedang, dan kemampuan tinggi, kemudian peneliti berkonsultasi dengan guru mata pelajaran matematika di kelas tersebut untuk mendapatkan informasi mengenai kecakapan komunikasi subjek penelitian. Hal ini dilakukan agar peneliti memperoleh subjek penelitian yang komunikatif dan mewakili masing-masing kelompok kemampuan matematika siswa.

Setelah subjek penelitian telah didapatkan, maka subjek penelitian diberikan intsrumen tes berpikir aljabar berupa soal program linear dan melakukan wawancara yang dilakukan sebanyak dua kali dengan waktu yang berbeda. Setelah itu, dari hasil soal program linear dan wawancara subjek dilakukan analisis dalam menyusun deskripsi berpikir aljabar siswa kelas XI dalam menyelesaikan soal program linear.

\section{HASIL DAN PEMBAHASAN}

\section{Siswa Berkemampuan Matematika Rendah}

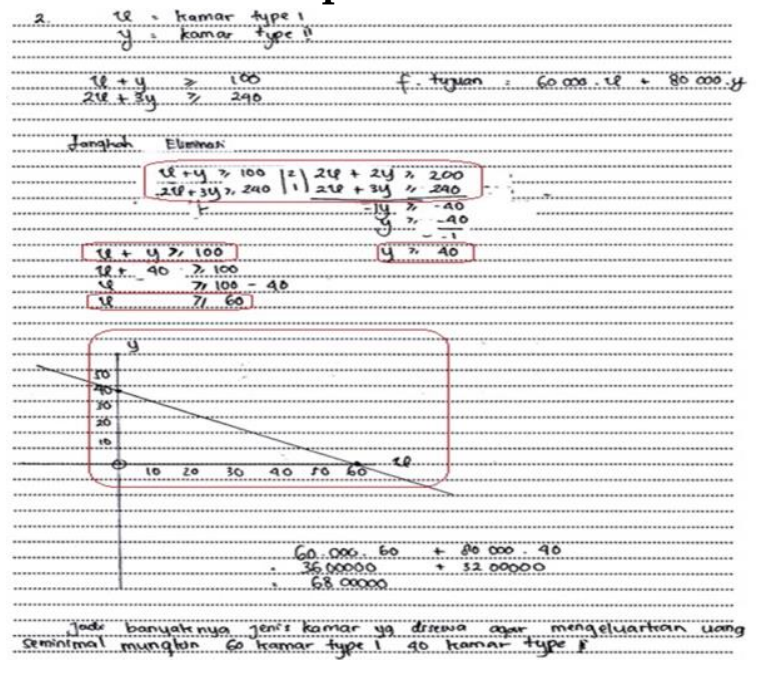

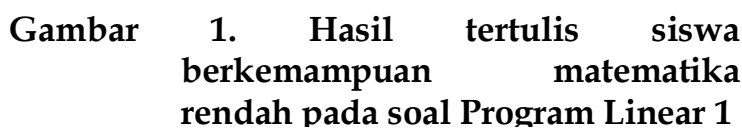

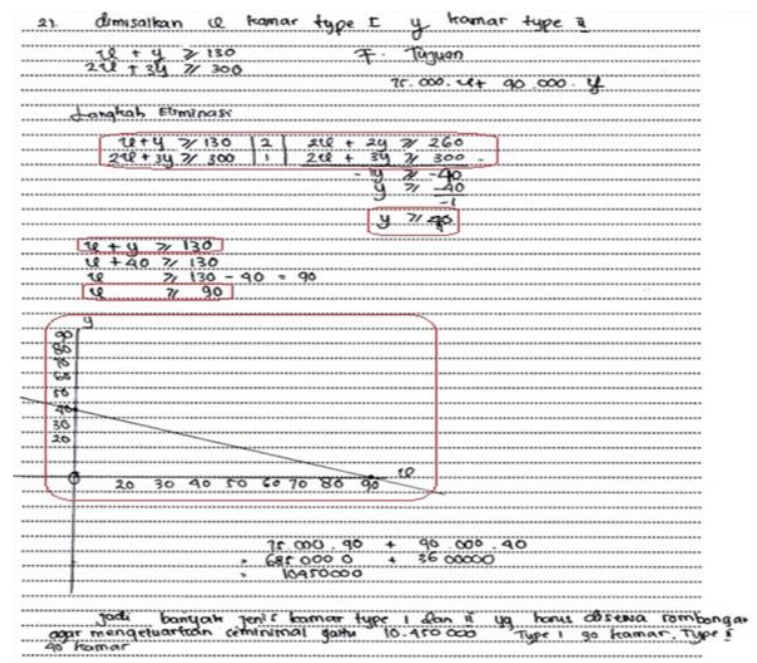

Gambar 2. Hasil tertulis siswa berkemampuan matematika rendah pada soal Program 
Pada komponen alat berpikir matematika, subkomponen kemampuan pemecahan masalah, siswa berkemampuan matematika rendah menuliskan informasi kedalam bentuk simbol. Selain itu, siswa berkemampuan matematika rendah menggunakan bentuk simbol yang telah ditetapkan dalam bentuk persamaan dan pertidaksamaan, dan menyatakan pertidaksamaan yang didapatkan ke dalam bentuk grafik. Hal ini menunjukkan bahwa siswa berkemampuan matematika rendah menggunakan beberapa strategi pemecahan masalah yaitu pemisalan, pemodelan, dan bentuk grafik.

Pada subkomponen kemampuan representasi, siswa berkemampuan matematika rendah menceritakan kembali permasalahan yang diberikan dengan sesekali melihat permasalahan yang diberikan, membuat representasi dari permasalahan berupa model matematika dan menyatakan representasi yang dibuat telah mewakili informasi yang diberikan.

Pada subkomponen kemampuan penalaran kuantitatif, siswa berkemampuan matematika rendah mengidentifikasi unsur-unsur penting suatu masalah untuk merencanakan penyelesaian masalah. Siswa berkemampuan matematika rendah mengidentifikasi apa yang diketahui pada masalah dan mengenali perintah dari masalah tersebut, serta menentukan langkah yang digunakan untuk menyelesaikan masalah yang diberikan.

Pada komponen ide dasar aljabar, subkomponen aljabar sebagai bahasa matematik, siswa berkemampuan matematika rendah memahami arti dari variabel dan menyebutkan bentuk-bentuk dari variabel. Hal ini ditunjukkan dengan siswa berkemampuan matematika rendah menggunakan variabel yang konsisten dalam menyelesaikan masalah yang diberikan, melakukan manipulasi aljabar untuk mendapatkan penyelesaian walaupun terdapat kesalahan, serta tidak dapat sepenuhnya menjelaskan arti dari penyelesaian yang diperoleh.

Pada subkomponen aljabar sebagai alat untuk fungsi dan pemodelan matematika, siswa berkemampuan matematika rendah merepresentasikan ide matematika dengan menggunakan bentuk persamaan, pertidaksamaan, grafik, dan kata-kata. Siswa berkemampuan matematika rendah memodelkan permasalahan dalam bentuk persamaan dan pertidaksamaan. Kemudian, siswa berkemampuan matematika rendah menggambar grafik daerah penyelesaian pertidaksamaan pada koordinat kartesius. Kemudian, siswa berkemampuan matematika rendah mendeskripsikan solusinya dalam bentuk kata-kata. Siswa berkemampuan matematika rendah bekerja dengan pola input/output walaupun apa yang dilakukan oleh siswa berkemampuan matematika rendah tidak sesuai dengan konsep. 


\section{Siswa Berkemampuan Matematika Sedang}

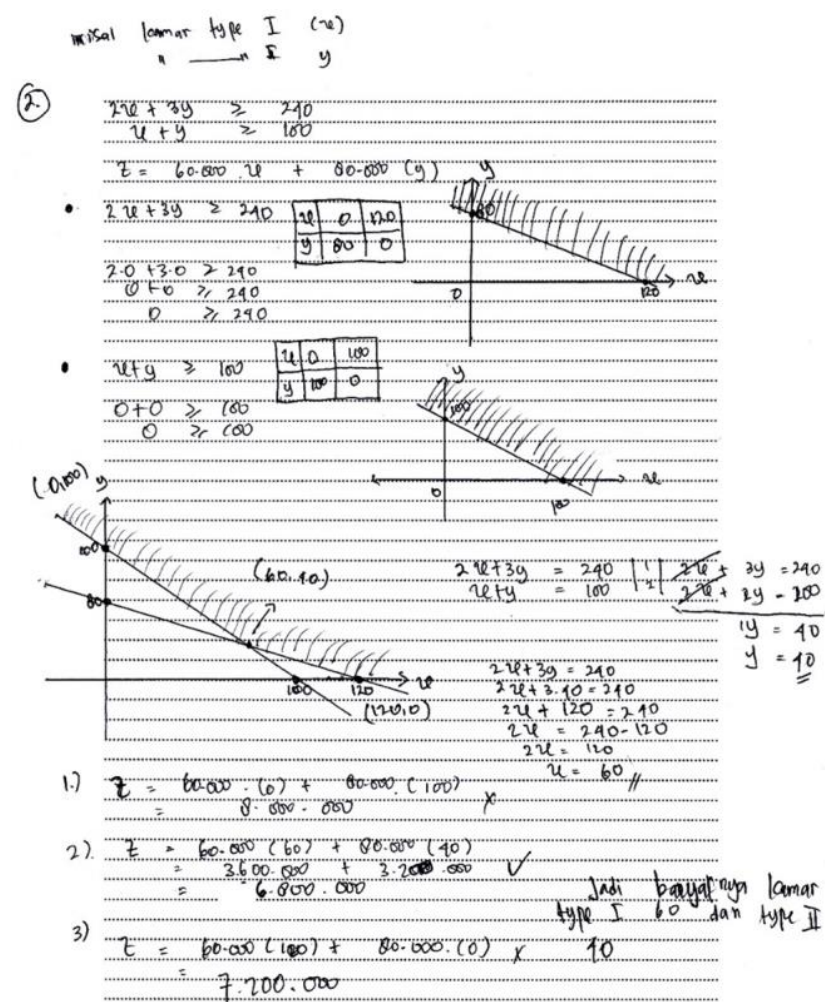

Gambar 3. Hasil tertulis siswa berkemampuan matematika sedang pada soal Program Linear 1

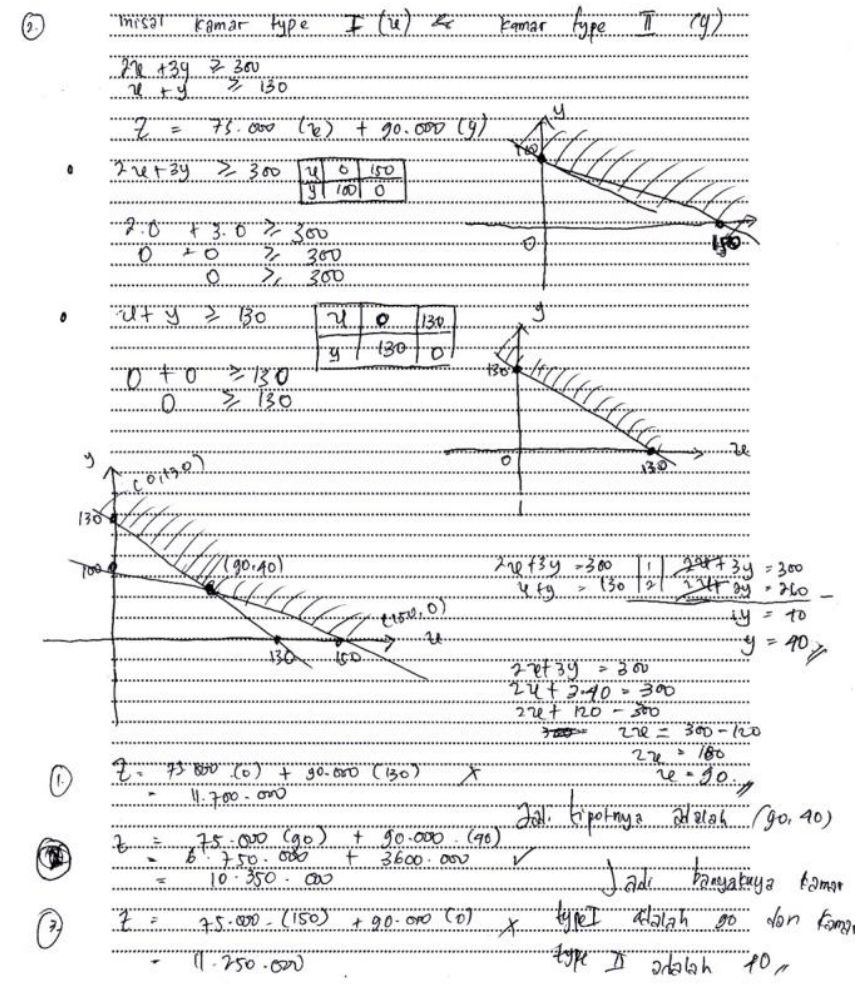

Gambar 4. Hasil tertulis siswa berkemampuan matematika sedang pada soal Program Linear 2

Pada komponen alat berpikir matematika, subkomponen kemampuan pemecahan masalah, siswa berkemampuan matematika sedang menuliskan informasi kedalam bentuk simbol. Selain itu, siswa berkemampuan matematika sedang menggunakan bentuk simbol yang telah ditetapkan dalam bentuk persamaan dan pertidaksamaan, dan menyatakan pertidaksamaan yang didapatkan ke dalam bentuk grafik. Hal ini menunjukkan bahwa siswa berkemampuan matematika sedang menggunakan beberapa strategi pemecahan masalah yaitu pemisalan, pemodelan, dan bentuk grafik.

Pada subkomponen kemampuan representasi, siswa berkemampuan matematika sedang menceritakan kembali permasalahan yang diberikan dengan membaca permasalahan, membuat representasi dari permasalahan berupa model matematika dan menyatakan representasi yang dibuat telah mewakili informasi yang diberikan.

Pada subkomponen kemampuan penalaran kuantitatif, siswa berkemampuan matematika sedang mengidentifikasi unsur-unsur penting suatu masalah untuk merencanakan penyelesaian masalah. Siswa berkemampuan matematika sedang mengidentifikasi apa yang diketahui pada masalah dan mengenali perintah dari masalah tersebut, serta 
menentukan langkah yang digunakan untuk menyelesaikan masalah yang diberikan.

Pada komponen ide dasar aljabar, subkomponen aljabar sebagai bahasa matematik, siswa berkemampuan matematika sedang memahami arti dari variabel dan menyebutkan bentuk-bentuk dari variabel. Hal ini ditunjukkan dengan siswa berkemampuan matematika sedang menggunakan variabel yang konsisten dalam menyelesaikan masalah yang diberikan, melakukan manipulasi aljabar untuk mendapatkan penyelesaian, serta dapat menjelaskan arti dari penyelesaian yang diperoleh.

Pada subkomponen aljabar sebagai alat untuk fungsi dan pemodelan matematika, siswa berkemampuan matematika sedang merepresentasikan ide matematika dengan menggunakan bentuk persamaan, pertidaksamaan, tabel, dan grafik. Siswa berkemampuan matematika sedang memodelkan permasalahan dalam bentuk persamaan dan pertidaksamaan. Kemudian, siswa berkemampuan matematika sedang membuat tabel yang digunakan untuk membantu dalam membuat grafik. Kemudian, siswa berkemampuan matematika sedang menggambar grafik daerah penyelesaian pertidaksamaan pada koordinat kartesius. Siswa berkemampuan matematika sedang bekerja dengan pola input/output. Hal ini ditunjukkan dengan siswa berkemampuan matematika sedang menguji beberapa titik pada fungsi kendala untuk menentukan nilai optimum.

\section{Siswa Berkemampuan Matematika Tinggi}
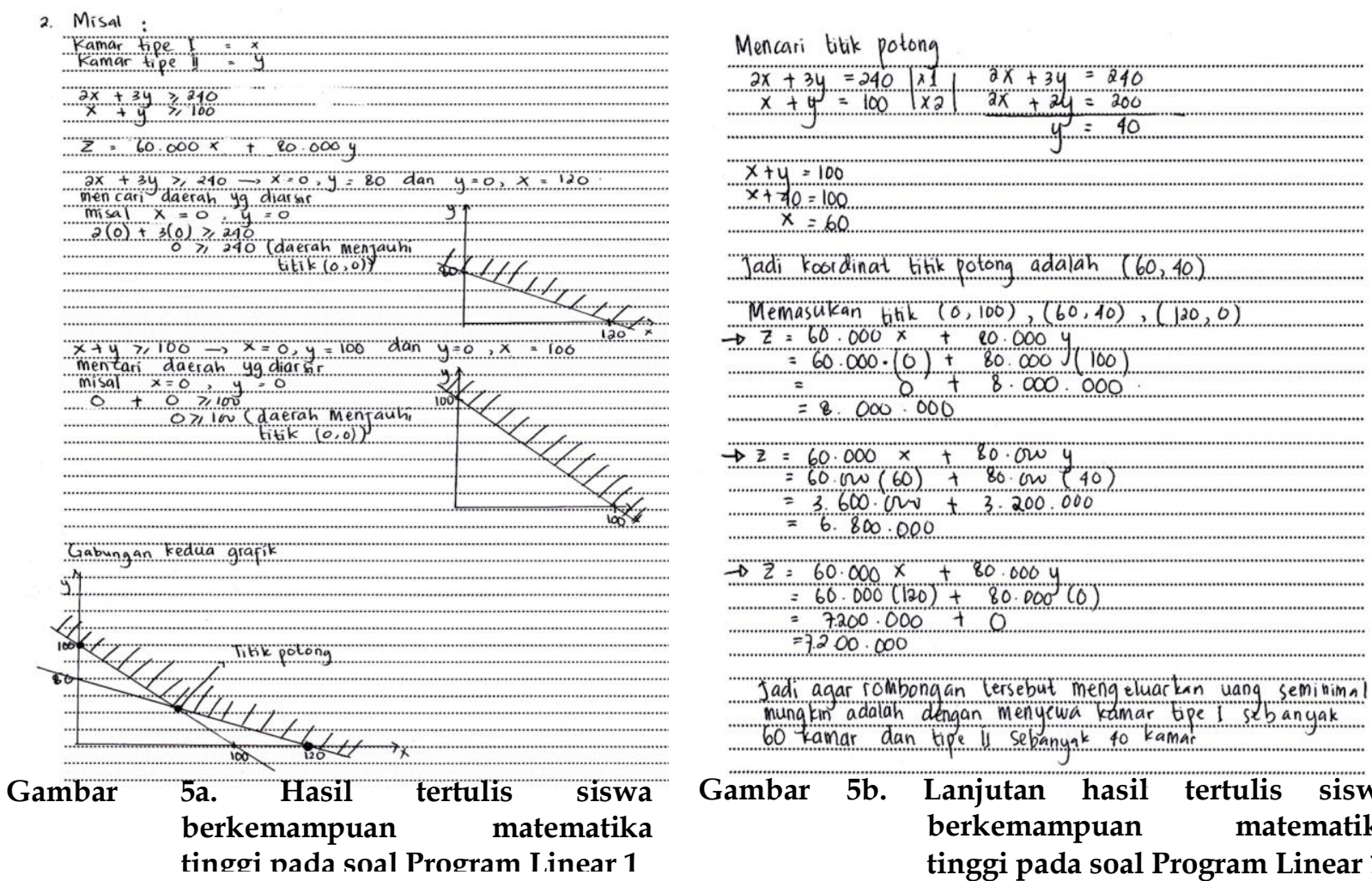
Gambar 5b. Lanjutan hasil tertulis siswa berkemampuan matematika tinggi pada soal Program Linear 1




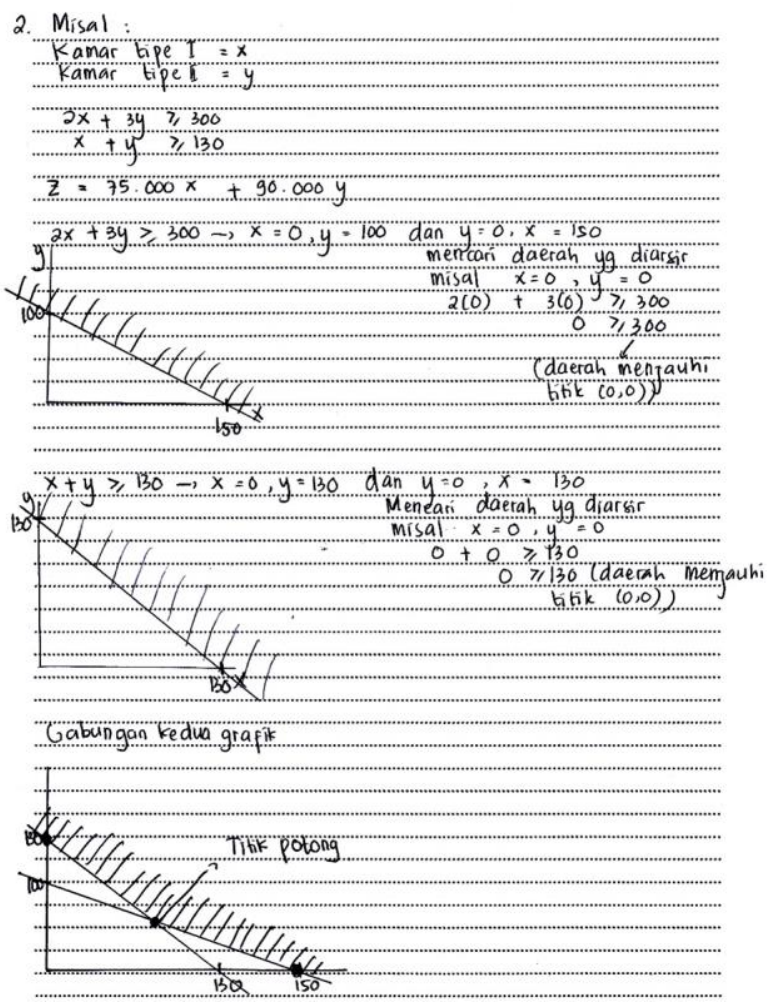

Gambar 6a. Hasil tertulis siswa berkemampuan matematika tinggi pada soal Program Linear 2

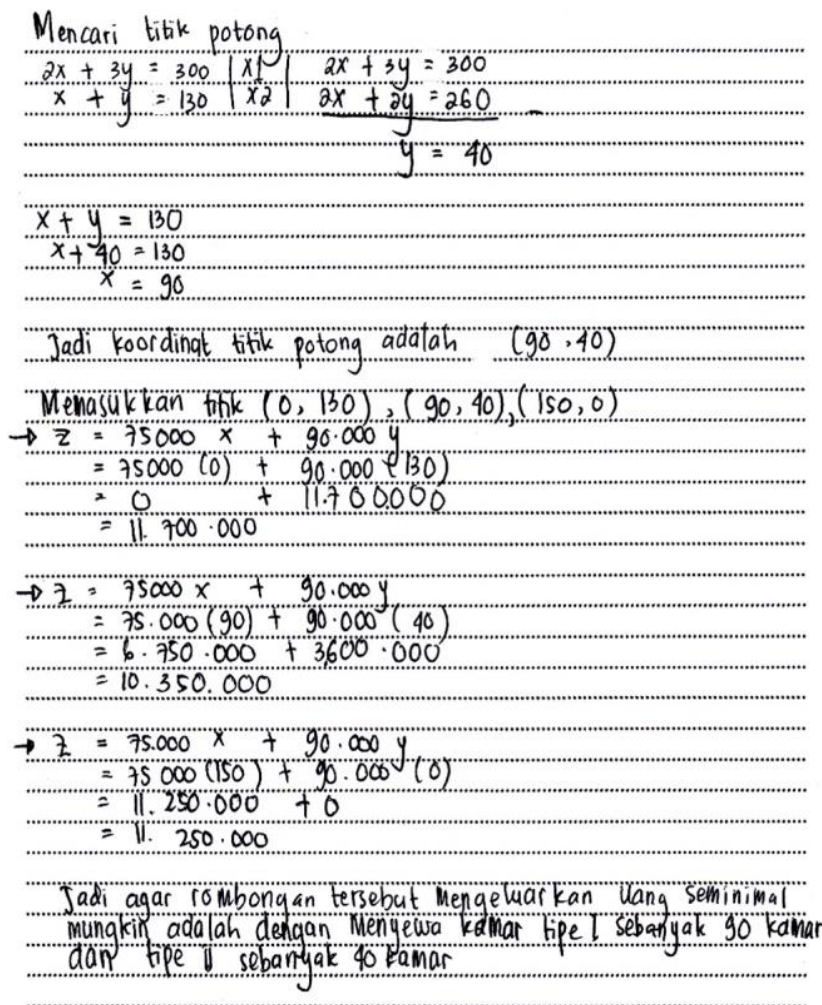

Gambar 6b. Lanjutan hasil tertulis siswa berkemampuan matematika tinggi pada soal Program Linear 2

Pada komponen alat berpikir matematika, subkomponen kemampuan pemecahan masalah, siswa berkemampuan matematika tinggi menuliskan informasi kedalam bentuk simbol. Selain itu, siswa berkemampuan matematika tinggi menggunakan bentuk simbol yang telah ditetapkan dalam bentuk persamaan dan pertidaksamaan, dan menyatakan pertidaksamaan yang didapatkan ke dalam bentuk grafik. Hal ini menunjukkan bahwa siswa berkemampuan matematika tinggi menggunakan beberapa strategi pemecahan masalah yaitu pemisalan, pemodelan, dan bentuk grafik.

Pada subkomponen kemampuan representasi, siswa berkemampuan matematika tinggi menceritakan kembali permasalahan yang diberikan dengan bahasanya sendiri, membuat representasi dari permasalahan berupa model matematika dan menyatakan representasi yang dibuat telah mewakili informasi yang diberikan.

Pada subkomponen kemampuan penalaran kuantitatif, siswa berkemampuan matematika tinggi mengidentifikasi unsur-unsur penting suatu masalah untuk merencanakan penyelesaian masalah. Siswa berkemampuan matematika tinggi mengidentifikasi apa yang diketahui pada masalah dan mengenali perintah dari masalah tersebut, serta 
menentukan langkah yang digunakan untuk menyelesaikan masalah yang diberikan.

Pada komponen ide dasar aljabar, subkomponen aljabar sebagai bahasa matematik, siswa berkemampuan matematika tinggi memahami arti dari variabel dan menyebutkan bentuk-bentuk dari variabel. Hal ini ditunjukkan dengan siswa berkemampuan matematika tinggi menggunakan variabel yang konsisten dalam menyelesaikan masalah yang diberikan, melakukan manipulasi aljabar untuk mendapatkan penyelesaian, serta dapat menjelaskan arti dari penyelesaian yang diperoleh.

Pada subkomponen aljabar sebagai alat untuk fungsi dan pemodelan matematika, siswa berkemampuan matematika tinggi merepresentasikan ide matematika dengan menggunakan bentuk pertidaksamaan, grafik, dan kata-kata. Siswa berkemampuan matematika tinggi memodelkan permasalahan dalam bentuk pertidaksamaan. Kemudian, siswa berkemampuan matematika tinggi menggambar grafik daerah penyelesaian pertidaksamaan pada koordinat kartesius. Siswa berkemampuan matematika tinggi bekerja dengan pola input/output. Hal ini ditunjukkan dengan siswa berkemampuan matematika tinggi menguji beberapa titik pada fungsi kendala untuk menentukan nilai optimum.

\section{KESIMPULAN DAN SARAN}

\section{KESIMPULAN}

Berdasarkan hasil dan pembahasan yang telah dilakukan dapat ditarik kesimpulan bahwa dari tiga subjek yang mewakili kelompok kemampuan matematika rendah, kemampuan matematika sedang, dan kemampuan matematika tinggi, pada komponen alat berpikir matematika, subkomponen kemampuan pemecahan masalah, siswa berkemampuan matematika rendah, sedang, dan tinggi menuliskan informasi kedalam bentuk simbol dan menggunakan trategi pemecahan masalah dengan pemisalan, pemodelan, dan bentuk grafik.

Pada subkomponen kemampuan representasi, siswa berkemampuan matematika rendah dan sedang menceritakan kembali permasalahan yang diberikan dengan sesekali membaca soal. Namun, siswa berkemampuan matematika tinggi menceritakan permasalahan dengan bahasanya sendiri. Selanjutnya ketiga siswa membuat representasi dari permasalahan berupa model matematika dan menyatakan bahwa representasi yang dibuat telah mewakili informasi yang diberikan.

Pada subkomponen kemampuan penalaran kuantitatif, siswa berkemampuan matematika rendah, sedang, dan tinggi mengidentifikasi unsur-unsur penting suatu masalah untuk merencanakan penyelesaian masalah. Siswa berkemampuan matematika rendah, sedang, dan tinggi juga mengidentifikasi apa yang diketahui pada masalah dan mengenali 
perintah dari masalah tersebut, serta menentukan langkah yang digunakan untuk menyelesaikan masalah yang diberikan.

Pada komponen ide dasar aljabar, subkomponen aljabar sebagai bahasa matematik, siswa berkemampuan matematika rendah, sedang, dan tinggi memahami arti dari variabel dan menyebutkan bentuk-bentuk dari variabel. Hal ini ditunjukkan dengan siswa berkemampuan matematika rendah, sedang, dan tinggi menggunakan variabel yang konsisten dalam menyelesaikan masalah yang diberikan, siswa berkemampuan matematika sedang dan tinggi melakukan manipulasi aljabar untuk mendapatkan penyelesaian, serta dapat menjelaskan arti dari penyelesaian yang diperoleh. sedangkan siswa berkemampuan rendah melakukan kesalahan dalam memanipulasi dan tidak dapat sepenuhnya menjelaskan arti dari penyelesaian yang diperoleh.

Pada subkomponen aljabar sebagai alat untuk fungsi dan pemodelan matematika, siswa berkemampuan rendah merepresentasikan dengan menggunakan bentuk persamaan, pertidaksamaan, grafik, dan kata-kata. Siswa berkemampuan matematika sedang merepresentasikan dengan menggunakan bentuk persamaan, pertidaksamaan, tabel, dan grafik. Sedangkan siswa berkemampuan matematika tinggi merepresentasikan dengan menggunakan bentuk pertidaksamaan, grafik, dan kata-kata. Selanjutnya, siswa berkemampuan matematika rendah, sedang, dan tinggi bekerja dengan pola input/output. Hal ini ditunjukkan dengan menguji beberapa titik pada fungsi kendala untuk menentukan nilai optimum. Walaupun yang dilakukan oleh siswa berkemampuan rendah tidak sesuai dengan konsep.

\section{SARAN}

Dari hasil penelitian ini, didapatkan informasi deskripsi berpikir aljabar siswa kelas XI memiliki sedikit perbedaan pada masing-masing indikator. Deskripsi berpikir aljabar siswa berkemampuan matematika sedang dan siswa berkemampuan matematika tinggi dalam menyelesaikan soal program linear lebih baik dibandingkan dengan deskripsi berpikir aljabar siswa berkemampuan matematika rendah. Sehingga, untuk selanjutnya diharapkan kepada para pendidik untuk memberikan latihan dan bimbingan kepada siswa berkemampuan matematika rendah agar dapat mengembangkan berpikir aljabar yang dimilikinya.

\section{DAFTAR RUJUKAN}

Kieran, Carolyn. (2004). Algebraic thinking in the early grades: What is it?. The mathematics educator. Vol.8, No.1 2004, Pp. 139-151 
Kieran, Carolyn. (2017). Seeking, using, and expressing structure in numbers and numerical operations: A fundamental path to developing early algebraic thinking. https://link.springer.com/chapter/10.1007/978-3-319-68351-5_4

Kriegler, Shelly. (2008). Just What is Algebraic Thinking? Submitted for Algebraic Concepts in the Middle School A special of Mathematics Teaching in the Middle School. Online. http:/ / math630801teachingofalgebraicconcepts.pbworks.com/f/J ust+What+is+Algebraic+Thinking+Kriegler+1-18-11.pdf. Diakses pada tanggal 30 Januari 2019

Krismanto. Al. (2004). Diklat instruktur/pengembang matematika smp jenjang dasar. Yogyakarta: Departemen Pendidikan Nasional Direktorat Jenderal Pendidikan Dasar dan Menengah Pusat Pengembangan Penataran Guru Matematika

Patton, Barba \& Santos, Estella De Los. (2012). Analyzing algebraic thinking using "gues my number" problems". International journal of instruction. Vol. 5, No. 1. Pp. 5-22

Ratumanan, T.G dan Lauren. (2003). Evaluasi hasil belajar yang relevan dengan kurikulum berbasis kompetensi. Surabaya: Unesa University Press

Windsor, Will. (2010). Algebraic thinking: a problem solving approach. Len sparrow, barry Kissane, and chris hurst (ed), shaping the future of mathematics education proceeding oh the $33^{\text {rd }}$ annual conference of the mathematics education research group of Australasia. John Curtin College of the Art, Fremantle, 3-7 July 2010 